\title{
TMS/TFRS Uygulamalarının Oran Analizine Muhtemel Etkileri
}

\author{
Tekin YENIGÜN * \\ Oğuzhan AYDEMİR **
}

\section{ÖZET}

Küreselleşme ile birlikte uluslararası düzeyde işletme karşılaştırmaları ve işletme değerlemesi önemli bir konu haline gelmistir. Fakat ülkelerin farkl muhasebe sistemlerine sahip olmaları işletmelerin karşılaş̧ırılmalarında ve analizlerinde sorunlara yol açmaktadır. Bundan dolayı birçok ülke ortak bir dil arayışı amacıyla Uluslararası Muhasebe Standartları (UMS) /Uluslararası Finansal Raporlama Standartlarını (UFRS) benimsemiştir. Bu çalışma ile Türkiye'de de Türkiye Muhasebe Standartları (TMS) ve Türkiye Finansal Raporlama Standartları (TFRS) adı ile belirli ölçüde uygulanmaya başlayan bu standartların oran analizine olan muhtemel etkileri incelenmektedir. TMS/TFRS uygulamalarının mali tablolar üzerinde kesin etkilerinin olmasına rağmen bunun finansal oranlar üzerindeki etkisi işletmeden işletmeye ve dönem içerisindeki faaliyetlere göre farklllıklar gösterebilir. Bu nedenle, oran analizinde önemli olan ayn muhasebe politikalarına ve standartlara göre hazırlanmış işletme mali tablolarının kullanılarak hazırlanmış olan oranların karşılaştırılmasıdır. Bu çalışma ile TMS/TFRS uygulamalarının mali tablolar ve dolayısı ile oran analizleri üzerindeki etkilerinin ortaya konması amaçlanmaktadır. Bu doğrultuda özellikle TMS/TFRS'ye geçiş sonucu değişiklik gösteren hesaplar ve bunun oran analizine olan etkileri örnekler yardımıyla açıklanmaktadır.

Anahtar Kelimeler: TMS/TFRS, UMS/UFRS, Oran Analizi.

JEL Sinıflandirması: M41, M48.

\section{The possible impacts of TAS/ TFRS Applications on Ratio Analysis}

\section{ABSTRACT}

Comparisons and valuations of firms at an international level have become an important subject along with globalization. However having different accounting systems of countries causes troubles in comparisons and analysis of firms. Therefore, many countries adopted International Accounting Standards (IAS) / International Financial Reporting Standards (IFRS) for the purpose of seeking a common language in accounting. In this study, the possible impacts of these standards which are partially used with the name of Turkish Accounting Standards (TAS) and Turkish Financial Reporting Standards (TFRS) in Turkey,on ratio analysis is examined. Although there are certain impacts of TAS/TFRS applications on financial statements, the impact of these on financial ratios can be different according to firms and activities in the period. Therefore, the important issue in ratio analysis is to compare ratios obtained from financial statements which are prepared with using the same accounting policies and standards. In this study, we aim to present the effects of TAS/TFRS applications on financial statements and accordingly ratio analysis. For this purpose, some accounts changed with TAS/TFRS and the impacts of this on ratio analysis are explained by examples.

Keywords: TAS/TFRS, IAS/IFRS, Ratio Analysis.

Jel Classification: M41, M48.

\footnotetext{
* Dr. Tekin Yenigün, Namık Kemal Üniversitesi, tyenigun@nku.edu.tr

${ }^{* *}$ Doç. Dr. Oğuzhan Aydemir, Namık Kemal Üniversitesi, İktisadi ve İdari Bilimler Fakültesi, aydemir69@gmail.com
} 


\section{GíRiş}

Dünya'da yaşanan küreselleşme akımı ile birlikte çokuluslu işletmelerin ve uluslararası yatırımcıların sayısı artmakta ve dünya tek bir coğrafi bölge haline gelmektedir. $\mathrm{Bu}$ ortamda ülkelerin ve dolayısıyla işletmelerin değişik muhasebe sistemlerine sahip olmaları işletme değerlendirilmelerinde ve karşılaştırılmalarında büyük sıkıntılar yaratmaktadır. Diğer bir değişle, bu ortamda farklı muhasebe uygulamalarına sahip işletmelerinin karşılaştırılmaları ve uluslararası yatırımcıların işletmeleri analiz etmeleri zorlaşmaktadır. Bununla birlikte, çokuluslu işletmelerin farklı ülkelerde faaliyet gösteren şubelerinin yeknesak bir muhasebe sistemine sahip olmaları hem işletme yönetimlerinin hem de kredi kuruluşlarının ve uluslararası yatırımcılarının yapacakları analizlerde kolaylık sağlayacaktır. Bu bağlamda tüm işletmeler tarafından ortak muhasebe standartlarının uygulanması büyük önem arz etmektedir. $\mathrm{Bu}$ çalışmada Türkiye'de Tekdüzen Muhasebe Sisteminden Uluslararası Muhasebe Standartlarına geçişin işletmelerin mali tabloları ve finansal oranları üzerindeki muhtemel etkileri incelenmektedir. Bu bağlamda, Uluslararası Muhasebe Standartlarının uygulanması ile birlikte değişiklik gösteren hesaplar, yeni hesaplar ve hesap grupları ve bunların oran analizi üzerindeki muhtemel etkileri örnek muhasebe kayıtları yardımıyla açıklanmaktadır.

Uluslararası Muhasebe Standartları, kâr veya kapsamlı kâr yanında bilançoda varlıklar, borçlar ve özkaynak hesaplarını etkileyen gerçeğe uygun muhasebeye dayanmaktadır (Blanchette, Racicot ve Girard, 2011). Buna rağmen, Uluslararası Muhasebe Standartlarının uygulanması sonucu finansal oranlardaki değişimin artış veya azalış yönünde olacağına yönelik kesin kuralların ortaya konması doğru olmayacaktır. Bunun nedeni ise Uluslararası Muhasebe Standartlarına geçişle birlikte bir oranın hem payını hem de paydasını etkileyebilecek birçok değişikliğin olma olasılığıdır. Burada önemli olan pay veya paydadaki değişimin oranıdır. Kısacası, işletmelerin faaliyetlerine bağlı olarak standartların uygulanması sonucu bir işletmenin belirli bir oranında artı̧ meydana gelebilirken diğer bir işletmede etki kendisini azalış şeklinde gösterebilir. Bu nedenle çalı̧̧mada belirli standartların oranlar üzerindeki muhtemel etkileri genel olarak ele alınacaktır.

$\mathrm{Bu}$ noktada önemli olan Uluslararası Muhasebe Standartlarının oranlar üzerinde olumlu veya olumsuz etkisinin olacağına yönelik genelleme yapmaktan çok (-ki bunu tespit etmek de çoğu zaman doğru değildir) her bir standardın finansal tablolar ve dolayısıyla oranlar üzerindeki muhtemel etkilerini belirlemek ve yapılacak analizlerde bunları dikkate almaktır.

Özetle, Uluslararası Muhasebe Standartları ile uyumlu Türkiye Muhasebe Standartları/ Türkiye Finansal Raporlama Standartları'nın ( TMS/TFRS) uygulanmasıyla, ülkemizdeki işletmelerin işletmelerin finansal tabloları üzerinden hesaplanan her bir oranın payını veya paydasını hem azalış hem de artış şeklinde etkileyebilecek birçok değişiklikler ortaya çıkabilir. Bu değişimlerin büyüklüğü ise işlemin niteliğine göre farklılık gösterecektir. Örneğin, TMS 2 Stoklar standardına göre stoklar maliyet ile net gerçekleşebilir değerin düşük olanı ile değerlenir ve net gerçekleşebilir değerin düşük olması durumunda değer düşüklüğü 
için karşılık ayrılır. Bu ise dönen varlıklar toplamının düşmesine neden olur. Bununla birlikte TFRS 5'e göre bir yıl içinde satılacak olan bir duran varlık gerekli koşullar sağlandığında dönen varlıklara alınır ve dönen varlıkların artmasına neden olur. Bu da göstermektedir ki işlemin niteliğine bağlı olarak bir grup toplamında artış da azalış da olabilir. Burada belirtilmesi gereken konu TMS/TFRS uygulamalarının finansal tabloları kesinlikle etkilediğidir. Fakat etkinin yönü ve derecesi işletmeden işletmeye veya dönem içerisindeki faaliyetlere göre değişecektir. Bu nedenle finansal oranlar üzerindeki etkilerin derecesi veya yönü zamana veya işletmeden işletmeye farklılık gösterebilir.

Finansal tablolar analizi sonucu elde edilecek oranların birçoğu için standart bir oran bulunmadığı için elde edilen oranların sektör ortalaması ve işletmenin geçmiş yıl oranları ile karşılaştırılması gerekmektedir. İşletmeler arası karşılaştırmaların yapılabilmesi işletmelerin aynı muhasebe sistemini uygulamaları ile, mevcut oranların işletmelerin geçmiş yıl oranları ile karşılaştırılabilmesi ise aynı muhasebe sisteminin uygulanması sonucu elde edilecek finansal tabloların kullanılmaları ile mümkün olacaktır. Hatta bu nedenle, muhasebe politikası değişikliklerinin etkisi geriye dönük olarak uygulanmakta ve böylece mali tabloların karşılaştırılabilir olması sağlanmaktadır.

$\mathrm{Bu}$ çalışmada TMS/TFRS uygulamalarının finansal oranlar üzerindeki muhtemel etkileri tartışılmaktadır. Çalışmanın ikinci bölümünde Uluslararası Muhasebe Standartlarının benimsenmesi sonucu finansal oranlarda yaşanabilecek değişimler ile ilgili literatür taraması yer almaktadır. Üçüncü bölümde ise bazı TMS/TFRS uygulamalarının işletmelerin belirli oranları üzerindeki muhtemel etkileri muhasebe kayıtları ile açıklanmakta, sonuç bölümünde genel bir değerlendirme yapılmaktadır.

\section{LITERATÜR TARAMASI}

Elitaş (2010) BİST'de işlem gören iki üretim işletmesinin 2005 yılı finansal tabloları üzerinde yapmış olduğu inceleme ile Ulusal Muhasebe Uygulama Esasları (UMUE) ile TMS/TFRS'ye göre hazırlanan finansal tabloları karşılaştırmış ve TMS/TFRS'ye göre hazırlanan finansal tabloların işletme oranlarında yarattı̆̆ 1 değişimleri test etmiştir. Araştırma sonucu, oranlar üzerindeki etkilerin çok açık olmadığını ve işletmeden işletmeye farklılıklar gösterdiğini ortaya çıkarmıştır. Örneğin, bir işletmede finansal kaldıraç oranı artarken diğer işletmede düşmektedir. $\mathrm{Bu}$ sonuçlar, TMS/TFRS'ye geçişin finansal oranlar üzerindeki etkilerinin işletmeden işletmeye ve ayrıca dönem içerisindeki faaliyetlere göre farklılıklar gösterebileceğini ortaya koymaktadır. Bu nedenle, birkaç işletme üzerinde yapılacak bir çalışma ile genelleme yapılması yanlış olacaktır. Ayrıca, BİST'de işlem gören işletmeler kayıtlarını standartlara göre değil TDHP'nına göre tutmakta ve sadece dönem sonlarında mali tablolarını standartlara uygun hale dönüştürmektedirler. Bu dönüştürme için tüm işlemlere ait gerekli verilerin yıl içindeki kayıtlardan sağlanıp sağlanamadığı da bir başka sorun olarak karşımıza çıkmakta ve yapılacak karşılaştırmalara sınırlamalar getirmektedir.

Ataman ve Özden (2009) yaptıkları çalışma ile TDHP'nına göre hazırlanan örnek bir işletmenin bilanço ve gelir tablosunu ele almışlardır. Daha sonra yaptıkları varsayımlar 
doğrultusunda düzeltme kayıtları yaparak mali tabloları TMS/TFRS'ye uyumlu hale getirmişlerdir. Her iki sisteme göre hazırlanan mali tablolar kullanılarak oran analizi gerçekleştirilmiş ve oranlar arasındaki farklılıklar ortaya konmuştur. Bu çalışma sonucunda TMS/TFRS'ye geçiş sonrası bazı oranlarda azalış bazılarında ise artış meydana gelmiştir. Örneğin, TMS/TFRS'ye uyumlu mali tablolar kullanılarak elde edilen cari oranda azalış görülmektedir. Bu sonuç Elitaş'ın (2010) bulgusu ile uyumlu değildir. Ayrıca, TMS/TFRS'ye geçiş sonrasında faaliyet oranlarında artış görülmektedir. Fakat faaliyet oranları hesaplanırken payda yer alan "Satılan Ticari Malların Maliyeti" ve "Net Satışlar" tutarlarında bir değişikliğin olmadığı görülmektedir. Normal koşullarda işletmelerin vadeli satışlarının olacağı ve bunlardan vade farkının ayrıştırılması yani vadeli satış tutarının bugünkü değerinin hesaplanarak satış tutarı olarak bu değerin alınması gerektiği göz önüne alınırsa bu tutarda da azalma olması gerekmektedir. Aynı şekilde vadeli mal alımlarında da vade farkının ayrıştırılmasının ticari malların maliyetini ve dolayısıyla satılan ticari malların maliyetini düşürmesi beklenmektedir. Tüm bunlar göstermektedir ki çalışmalarda ele alınan varsayımlara göre oranlarda artış da azalış da yaşanabilir. Kısacası TMS/TFRS'ye geçiş sonucu oranlardaki değişimin yönünü bildirmek ve genelleme yapmak çoğu oran için mümkün değildir.

Balcı (2012) yaptığı araştırmada Ataman ve Özden'in (2009) çalışmasını esas almış ve belirli varsayımlar doğrultusunda TDHP'nına göre hazırlanan bilanço ve gelir tablosunu TMS/TFRS'ye uygun hale dönüştürmüştür. Daha sonra dönüştürme öncesi ve sonrası elde edilen finansal oranlar karşılaştırılmıştır. Elde edilen sonuçlara göre dönüştürme sonrası dönem karı dönem zararına dönüşmüştür. Ayrıca uluslararası standartlara dönüşüm sonrası likidite ve karlılık oranlarının düşmesine rağmen finansal yapı ve faaliyet oranları artmıştır. Fakat çalışma sonuçları dikkatli bir şekilde yorumlanmalıdır. Bunun nedeni ise TFRS'ye dönüştürme esnasındaki varsayımların değişmesi ile birlikte elde edilen bu sonuçlarda da değişiklik görünebilir.

Terzi, Oktem ve Sen (2013) TMS/TFRS'ye geçişin Borsa İstanbul'a kota olan ve imalat sanayinde faaliyet gösteren işletmeler üzerindeki etkisini araştırmışlardır. Araştırma bulguları Genel Kabul Görmüş Muhasebe İlkelerine ve TMS/TFRS'ye göre hazırlanan mali tabloların istatistiksel olarak farklı olduklarını ortaya koymuştur. Anlamlı farklılıklar stoklar, duran varlıklar, uzun vadeli yabancı kaynaklar ve özsermaye hesaplarında belirlenmiştir. Aynı zamanda, cari oran, alacak devir hızı, varlık devir hızı, toplam yabancı kaynak/maddi duran varlıklar, duran varlık devir hızı, özsermaye devir oranı, kısa vadeli yabancı kaynak/ toplam yabancı kaynak ve kısa vadeli yabancı kaynak/toplam varlıklar oranları istatistiksel ve anlamlı olarak farkl111k göstermektedir.

Dimitrios, Nikolaos, Konstantinos, ve Dimitrios (2013) yaptıkları çalışma ile Atina Borsasında yer alan eski ve yeni kota olmuş işletmelerden oluşan iki grup işletmeyi ele alarak, UFRS'ye geçişin finansal oranlar üzerindeki etkilerinin olup olmadığını ve bu etkinin incelenen gruplar arasında farklılık gösterip göstermediğini incelemişlerdir. Araştırma 
sonucuna göre, UFRS'ye geçişte iki grupta yer alan işletmelerin oranları aynı şekilde etkilenmektedir. Ayn 1 zamanda, Yunanistan'da UFRS'nin benimsenmesinin ve uygulanmasının finansal oranların hesaplanmasında anlamlı etkisi bulunamamıştır.

Blanchette, Racicot ve Girard (2011) UFRS'ye geçişin finansal oranlar üzerindeki etkilerini belirlemek için Kanadalı işletmelerin aynı döneme ait hem UFRS hem de Kanada muhasebe sistemine göre hazırlanmış finansal tablolarını kullanmışlardır. Araştırma bulguları oranların oynaklığı ile ilgilidir. İlk kanıtlar, UFRS'yi erken benimseyenler için Kanada muhasebe sistemine göre hesaplanan oranlar ile karşılaştırıldığında UFRS'ye göre hesaplanan çoğu oranların önemli bir şekilde daha yüksek oynaklık gösterdiğini ortaya koymuştur. Aynı zamanda, farklılıkların istatistiki olarak anlamlı olmamasına rağmen oranların ortalama ve medyanları arasındaki farklılıklar incelenmiştir. Finansal oranların ortalama ve medyanlarının dağılımı UFRS'nin işletmelerin finansal durumlarını anlamlı bir şekilde etkilemediğini belirtmektedir. Fakat bazı durumlarda önemli özel aykırlıklar bulunmaktadır. Kısacası, UFRS'nin tüm finansal oranları anlamlı bir şekilde etkilememesine rağmen bireysel oranların düzeyinde dikkate değer farkl11ıklar vardır.

Blanchette, Racicot ve Sedzro (2013) Kanada'da Toronto Borsasinda faaliyet gösteren işletmeler üzerine bundan önce açıklanan çalışmalarına benzer bir araştırma yapmışlardır. Çalışma sonuçlarına göre, toplam düzeyde, mali tablo rakamları ve oranların ortalama ve medyanları Kanada muhasebe sistemine ve UFRS'ye göre istatistiksel olarak farklı değildir. Örneğin, cari oranın medyanı Kanada muhasebe sistemine göre 1,51 iken UFRS'ye göre hazırlanan mali tabloda 1,48 olarak hesaplanmıştır. Aynı şekilde Kanada muhasebe sistemine göre kaldıraç oranının medyanı ve varlıkların getirisinin medyanı sırasıyla 0,542 ve $\% 3,9 \mathrm{iken}$ UFRS'ye göre 0,533 ve $\% 4,9$ olmuştur.

Pazarskis, Alexandrakis, Notopoulos ve Kydros (2011)Atina borsasında yer alan 20 bilişim teknolojisi işletmesine ait 2005 öncesi yani UFRS öncesi ve sonrası finansal tablolar üzerinde yaptıkları araştırma (2005 yılında UFRS'ye geçilmiştir) ile UFRS uygulamalarının finansal oranlar üzerindeki etkileri araştırmışlardır. Bu amaçla, karlılık, faaliyet ve finansal yapı oranlarından toplam 12 oran ele alınmıştır. İlk önce 2002 tarihli finansal tablolar ile 2005 tarihli finansal tablolar karşılaş̧ırılmıştır. Elde edilen sonuçlara göre bu dönemler için finansal oranların hiçbiri UFRS'nin benimsenmesinden dolayı istatistiksel olarak anlamlı bir değişime sahip değildir. Aynı zamanda, UFRS'nin benimsenmesinin muhasebe tabanlı bilgi ve performans üzerinde belirgin bir etkisinin olduğuna dair kanıt bulunamamıştır. Diğer yandan UFRS öncesi ve sonrası 3'er yıllık mali tablolar ele alındığında UFRS'ye geçişin sadece FVÖK/Satı̧̧lar ve Uzun Vadeli Yabancı Kaynaklar/Özsermeye oranlarında istatistiki olarak anlamlı değişime neden olduğu görünmektedir.

Stent, Bradbury ve Hooks (2010) Yeni Zelanda Borsası'nda yer alan ve UFRS'yi benimsemiş 56 işletme (bunlardan 16 tanesi geçiş zorunlu olmadan UFRS'yi benimsemiştir) üzerinde yaptıkları araştırma ile UFRS'ye geçişin finansal tablo ve oranlar üzerindeki etkilerini araştırmışlardır. Araştırma sonuçları, özsermaye karlılı̆̆ı, varlıkların karlılığı, 
kaldıraç ve satışların getirisi oranlarının her birinin medyanının artı̆̆̆ını, aktif devir hızı medyanın ise düştügünü göstermiştir. Ayrıca, UFRS'ye geçişten küçük işletmeler büyük işletmelere göre daha az etkilenmişlerdir.

\section{TMS/TFRS VE ORANLAR ÜZERINDEKİ MUHTEMEL ETKILERİ}

$\mathrm{Bu}$ bölümde uluslararası muhasebe standartlarının mali tablolar ve sonuç olarak oranlar üzerindeki muhtemel etkileri ele alınmaktadır. Bu nedenle aşağıda seçilmiş olan bazı standartların ne tür bir değişime neden olabileceği ayrı ayrı ele alınmakta ve bu değişimlerin hangi oranlar üzerinde etkisinin olabileceği anlatılmaktadır.

\section{TFRS 5 Satış Amaçlı Eıde Tutulan Duran Varlıklar ve Durdurulan Faaliyetler}

"TFRS 5 Satış Amaçlı Elde Tutulan Duran Varlıklar ve Durdurulan Faaliyetler" Standardına göre işletme bir duran varlığını bir yıl içerisinde satmaya karar verdiğinde ve gerekli koşullar oluştuğunda defter değeri ile satış giderleri düşülmüş gerçeğe uygun değerinden düşük olanı ile dönen varlıklar içerisine alır (RG 16.03.2006, sayı:26110). Bu tam set TMS/TFRS uygulayanlar için geçerlidir. Böylece işletmenin cari oranında artış meydana gelecektir. Ayrıca bir maddi duran varlık satış amaçlı elde tutulan duran varlık olarak sınıflandırıldığında bu varlıkla ilgili borçlar satış amaçlı duran varlıklar ile ilgili borçlara aktarılacaktır (Gücenme Gençoğlu vd., 2013). Fakat bu durum yabancı kaynak toplamını değiştirmeyecek sadece hesap ismini değiştirecektir.

Örneğin: İşletme maliyet değeri 15.000 TL ve birikmiş amortismanı 6.000 TL olan makinesini satmaya ve satış amaçlı elde tutulan duran varlık olarak dönen varlıklara almaya karar vermiştir. Makinenin satış giderleri düşülmüş gerçeğe uygun değerinin $7.500 \mathrm{TL}$ olduğu tespit edilmiştir. Bu verilere göre yevmiye kaydı aşağıdaki şekilde olacaktır1.

Makinenin defter değeri $=15.000-6.000=9.000 \mathrm{TL}$

Gerçeğe uygun değeri $=7.500 \mathrm{TL}$

$\mathrm{Bu}$ verilere göre varlık düşük olan gerçeğe uygun değer üzerinden dönen varlıklara alınacaktır.

1.. Satış Amaçlı Elde Tutulan Varlıklar $\quad 7.500$

2.. Birikmiş Amortismanlar $\quad 6.000$

6.. Durdurulan Faaliyet Gider ve Zararları 1.500

2.. Makine, Tesis ve Cihazlar

15.000 /

Bu kayıt sonucu dönen varlıklar 7.500 TL artmış, duran varlıklar ise 9.000 TL azalmış olacaktır. Aradaki 1.500 TL'lik farkın gider olarak yazılması ise muhasebe karının azalmasına neden olacaktır.

\footnotetext{
${ }^{1}$ Çalışmada yer alan örnekler ve hesap planında Gücenme Gençoğlu vd., 2013'den faydalanılmıștır.
} 
$\mathrm{Bu}$ işlem sonucu işletmenin dönen varlık devir hızı azalacak ama duran varlık devir hızı artacaktır. Ayrıca işletmenin cari oranında da artış görünecektir. Fakat cari orandaki bu artışın geçici olduğu unutulmamalı ve geçmiş yıl oranları ile kıyaslamada bu durum dikkate alınmalıdır. Bununla birlikte, bilanço toplamında da $1.500 \mathrm{TL}$ azalış olacaktır. Bu durum aktif toplamı ile ilgili oranları (aktiflerin karlılı̆ı, aktif devir hızı vb.) etkileyecektir. Eğer örnekte gerçeğe uygun değer daha yüksek olsaydı, defter değeri esas alınacağından aktif toplamında ve bununla ilgili oranlarda herhangi bir değişiklik olmayacaktı. Bu da finansal oranlardaki değişimin yönünün varsayımlara bağlı olduğunu göstermektedir.

\section{TMS 2 Stoklar}

"TMS 2 Stoklar" standardına göre stoklar maliyet ile net gerçekleşebilir değerin (NGD) düşük olanı ile değerlenir ve net gerçekleşebilir değerin düşük olması durumunda değer düşüklüğü için karş1lı ayrılır (RG 15.01.2005, say1: 25701). Değer düşüklüğü stoklar ile ilgili olduğu için "654.Karş1lık Giderleri" hesabında değil satılan malların maliyeti ile brüt kar arasında yer alacak olan "Stok Değer Düşüklüğü Karşllık Giderleri" hesabına kayıt edilecektir (Gücenme Gençoğlu vd., 2013: 294). Bu ise dönen varlıklar toplamının ve aynı zamanda brüt karın düşmesine neden olacaktır.

Örneğin: Maliyet değeri 5.000 TL olan malların, tahmini satı̧ fiyatı $5.100 \mathrm{TL}$ ve tahmini satı̧s gideri $600 \mathrm{TL}$ olarak tespit edilmiş̧ir. Buna göre yapılması gereken kayıt aşă̆ıdaki gibidir.

Maliyet değeri $=5.000 \mathrm{TL}$

Net Gerçekleşebilir Değer= Tahmini Satış Fiyatı-Tahmini Satış Gideri=5.100-600= 4.500 TL

NGD < Maliyet Değeri olduğu için 5.000-4.500=500 TL stok değer düşüklüğü ayrilacaktır.

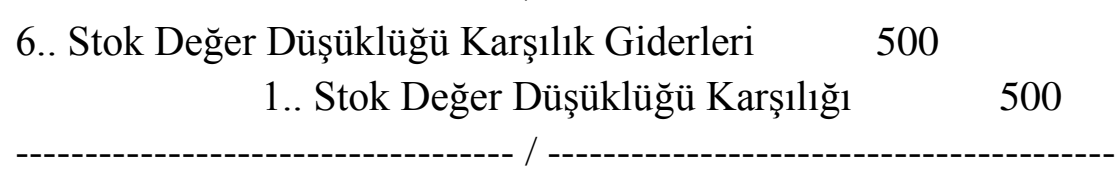

$\mathrm{Bu}$ kayda göre işletmenin dönen varlıklarında ve brüt kar tutarında düşüş olacaktır. Böylece cari oranda ve brüt kar marjında düşüş olacaktır. Bununla birlikte, dönen varlık devir hızı artacaktır.

Uluslararası Muhasebe Standartlarına göre vadeli varlık alım ve satımlarında vade farkının hesaplanarak ayrıştırılması ve vade farkının faiz geliri veya gideri olarak kaydedilmesi gerekmektedir (RG 15.01.2005, say1: 25701 ve RG 09.12.2005, say1: 26018). $\mathrm{Bu}$ durum tüm varlık alım ve satım işlemleri için geçerlidir. Örneğin vadeli ticari mal alımında mal alımının peşin fiyatına yani vade farksız satın alınıp alınmadığına bakılmaksızın ticari malın bugünkü değeri hesaplanacak ve mal bedeli bugünkü değer üzerinden kayda alınacaktır. Hesaplanan vade farkı ise ertelenmiş vade farkı giderleri olarak pasifi düzenleyici 
hesap olarak pasifte yer alacaktır. Bu durumda işletmenin hem aktif hem de pasif toplamı azalacaktır. Ertelenmiş faiz gideri gerçekleştiğinde yani tahakkuk ettiğinde gelir tablosuna vade farkı gideri (faiz gideri) olarak aktarılacaktır (Gücenme Gençoğlu vd., 2013: 277).

Örneğin: İşletme 6 ay vadeli 12.000 TL'lik ticari mal satın almıştır. Aylık emsal faiz oranı \%1'dir. Buna göre mal alım kaydı aşağıdaki şekilde olacaktır.

İlk önce 6 ay sonra ödenecek olan 12.000 TL'nin bugünkü değerinin hesaplanması gerekmektedir.

$$
B D=\frac{G D}{(1+i)^{n}}=\frac{12.000}{(1+0,01)^{6}}=11.305 T L
$$

$\mathrm{BD}=$ Bugünkü Değer

$\mathrm{GD}=$ Gelecek Değer

i= Faiz Oranı

n= Dönem Sayısı

Vade Fark1 $=12.000-11.305=695 \mathrm{TL}$

1.. Ticari Mallar

11.305

3.. Ertelenmiş Vade Farkı Giderleri 695

3.. Satıcilar

12.000

/

Bu kayda göre aktif ve pasif toplamı Tek Düzen Hesap Planına göre yapılacak kayda göre 695 TL daha düşük olarak kayıt edilmiş olacaktır. İlk ayın sonunda ise ertelenmiş vade fark1 giderlerine kayıt edilen tutarın ilk aya rastgelen 69,5 TL'si (695 x 0,01=69,5 TL) vade farkı giderlerine yani gelir tablosuna aktarılır ve stok satılıncaya kadar kanunen kabul edilmeyen gider olarak kabul edilir. Fakat bu çalışmada ertelenmiş vergi varlığ 1 ve ertelenmiş vergi borcu hesaplanmamış yani göz ardı edilmiştir. İlk ayın vade farkı gideri kaydı:

6.. Vade Fark1 Giderleri $\quad 69,50$

3.. Ertelenmiş Vade Farkı Giderleri $\quad 69,50$

Vade farkının ayrıştırılması ile işletmenin dönen varlıkları, kısa vadeli yabancı kaynaklar toplamı ve aktif toplamı azalacaktır. Sonraki dönemlerde vade farkı giderlerinin gelir tablosuna aktarılması ile birlikte muhasebe karı tutarı düşecektir. Diğer yandan ertelenmiş vade farkının zaman içerisinde vade farkı gideri olarak gelir tablosuna aktarılması işletmenin kısa vadeli yabancı kaynaklarının artmasına neden olacaktır. Böylece bu kalemler ile ilgili oranlarda da değişim yaşanacaktır. Fakat finansal oranlara olan etkisi işletmeden 
işletmeye farklı olacaktır. Örneğin, işletmenin cari oranı bu işlem öncesi 1'den büyük ise vade farkının ayrıştırılması sonucu stok ve borç tutarının aynı tutarda azalması cari oranı artıracaktır. Diğer yandan işletmenin cari oranı 1'den küçük olsaydı bu işlem sonucu cari oran düşecektir. Fakat bu işlem sonucu kesinlikle toplam varlıklarda azalış olacaktır. Buda aktif toplamı ile ilgili oranları etkileyecektir.

\section{TMS 16 Maddi Duran Varlıklar}

Vadeli maddi duran varlık satın alımında eğer ödeme normal kredi vadelerinin ötesine erteleniyorsa vade farkı ayrıştırılacak ve ilgili varlık peşin değeri ile mali tablolara alınacaktır (RG 31.12.2005, sayı: 26040). Vade farkı ise pasifi düzenleyici bir hesap olan ertelenmiş vade farkı giderlerine ve gerçekleştiklerinde de faiz gideri kapsamında gelir tablosuna alınacaktır. Böylece ilk alım esnasında hem aktif hem de pasif toplamı daha düşük görünecektir. Bu işlem sonucunda ayrılacak amortisman tutarları da daha az olacaktır.

Örneğin: İşletme 1 Şubat 2014 tarihinde 6 ay vadeli olarak 24.000 TL'ye tutarında bir makine satın almıştır. Ödemeyi her ay eşit taksitler (aylık $4.000 \mathrm{TL}$ ) halinde yapacaktır. İskonto oranı aylık \%1'dir. Buna göre yevmiye kaydı şu şekilde yapılacaktır.

Burada ilk yapılması gereken anüitenin bugünkü değeri formülü yardımıyla yapılacak ödemelerin bugünkü değerini hesaplamaktır.

$$
B D=A x \frac{(1+i)^{n}-1}{(1+i)^{n} x i}
$$

$\mathrm{A}=$ Eşit Ödemeler

$B D=4.000 x \frac{(1+0,01)^{6}-1}{(1+0,01)^{6} \times 0,01}=23.182 T L$

Ertelenmiş Vade Farkı Giderleri= $24.000-23.182=818 \mathrm{TL}$

2.. Tesis, Makine ve Cihazlar

23.182

3.. Ertelenmiş Vade Farkı Giderleri 818

3.. Diğer Borçlar

24.000 I

Buna göre ilk kayıt esnasında duran varlıklar ve kısa vadeli yabancı kaynaklar 818 TL daha düşük olarak kayıtlara alınacaktır. Bununla birlikte, her ayın sonunda ertelenmiş vade farkı giderlerinin ilgili aya ait kısmı vade farkı gideri olarak gelir tablosuna atılacağından kısa vadeli yabancı kaynaklarda aylar itibari ile bir artış olacaktır. Kısacası ertelenmiş vade farkı giderleri sayesinde borçların o anki gerçek tutarının görünmesi sağlanmaktadır. Bu nedenle 
reeskont işlemlerine benzerlik göstermektedir. Aralarındaki fark ise reeskont işleminin dönem sonunda, ertelenmiş vade farkı giderlerinin ise işlem anında hesaplanmasıdır. $\mathrm{Bu}$ işlemden maddi duran varlıklar ve aktif toplamı ile ilgili oranlar etkilenecektir. Örneğin, aktif devir hızı ve duran varlık devir hızı artacaktır. Diğer yandan kısa vadeli yabancı kaynak toplamının ilk işlem esnasında $818 \mathrm{TL}$ daha düşük olarak kayıtlara alınması likidite oranlarını daha yüksek gösterecektir.

Maddi duran varlık değer düşüklüğünün tespitinde "TMS 36 Varlıklarda Değer Düşüklüğü standardı” hükümleri uygulanır (RG 31.12.2005, sayı: 26040). Buna göre maddi duran varlığın geri kazanabilir değeri maliyet değerinden daha düşük ise maddi duran varlık için değer düşüklügü söz konusudur ve değer düşüklüğü için karşılık ayrılmalıdır. Geri kazanılabilir değer ise ilgili varlığın gerçeğe uygun değerinden satış giderleri düşülmüş net satış değeri ile kullanım değerinden büyük olanıdır. Kullanım değeri ise varlığın gelecekte yaratacağı nakit akımlarının bugüne iskonto edilmiş değeridir (Gücenme Gençoğlu vd., 2013:385).

Örneğin: İşletme maliyet değeri $60.000 \mathrm{TL}$, birikmiş amortismanı 10.000 TL ve 5 y1l ekonomik ömrü kalan makinesinin satış değerini 35.000 TL ve satış giderlerini $2.000 \mathrm{TL}$ olarak tahmin etmektedir. Makinenin gelecek 5 yılda yaratacağı tahmini net nakit girişleri aşağıda verilmektedir. Y1llık iskonto oranı \%10’dur.

\begin{tabular}{|l|l|l|l|l|l|}
\hline Yll & $\mathbf{1}$ & $\mathbf{2}$ & $\mathbf{3}$ & $\mathbf{4}$ & $\mathbf{5}$ \\
\hline Net Nakit Girişleri & 10.000 & 12.000 & 8.000 & 10.000 & 15.000 \\
\hline
\end{tabular}

Burada ilk yapılması gereken kullanım değerinin hesaplanmasıdır. Kullanım değeri gelecekteki nakit girişlerinin bugünkü değeridir. Buna göre;

$$
\text { Kullanım Değeri }=\frac{10.000}{(1+0,1)^{1}}+\frac{12.000}{(1+0,1)^{2}}+\frac{8.000}{(1+0,1)^{3}}+\frac{10.000}{(1+0,1)^{4}}+\frac{15.000}{(1+0,1)^{5}}
$$

\section{Kullanım Değeri $=41.163 \mathrm{TL}$}

Net Satış Fiyatı $=35.000-2.000=33.000 \mathrm{TL}$

Kullanım Değeri (41.163 TL) > Net Satış Fiyatı (33.000 TL) olduğu için Geri Kazanabilir Değer, büyük olan 41.163 TL olarak ele alınacaktır.

Defter Değeri $=60.000-10.000=50.000 \mathrm{TL}$

Defter Değeri (50.000 TL) > Geri Kazanabilir Değer (41.163 TL) olduğundan dolayı,

Değer Düşüklüğü= $50.000-41.163=8.837$ TL'dir. 


\section{6.. Karş1lık Giderleri 8.837}

2.. Maddi Dur. Var. Değer Düşüklüğü Karşılığ 8.837

Bu kayıt sonucunda duran varlıklar ve dolayısıyla toplam aktiflerde düşüş olacaktır. Aynı zamanda karşılık giderleri sonucu dönem karında azalma gerçekleşecektir. Böylece duran varlıklar, toplam aktifler ve dönem karı ile ilgili oranlarda değişiklik meydana gelecektir.

\section{TMS 38 Maddi Olmayan Duran Varlıklar}

Uluslararası Muhasebe Standartlarına göre şerefiye maddi olmayan duran varlıklar içerisinde değil ayrı bir grup olarak bilançoda yer almaktadır. Tam set TMS/TFRS'ye göre sınırlı ekonomik ömre sahip maddi olmayan duran varlıklar itfa edilirken sınırsız ekonomik ömre sahip maddi olmayan duran varlıklar itfa edilmez, değer düşüklüğü testine tabi tutulur (RG 17.03.2006, sayı: 26111). KOBİ TFRS'de ise maddi olmayan duran varlikların ekonomik ömrü belli olmasa da 10 yılda itfa edilir.

Tam set TMS/TFRS'ye göre yeniden değerleme yapılabilir ve değer artışı özkaynaklar içerisinde yer alır. Yeniden değerlemede varlığın defter değeri gerçeğe uygun değeri ile karşılaştırılır ve değer artışı veya değer düşüklüğü olup olmadığı tespit edilir. Varlığın değerindeki değişim oranına göre varlığın hem maliyet değeri hem de birikmiş itfa payları değiştirilir (Gücenme Gençoğlu vd., 2013).

Örneğin: İşletmenin "Haklar" hesabında yer alan ve maliyet bedeli 20.000 TL, birikmiş amortismanı 10.000 TL olan varlığın gerçeğe uygun değeri 12.000 TL'dir. Buna göre yapılması gereken kayıt;

Defter değeri $=20.000-10.000=10.000 \mathrm{TL}$

Değer artış oranı $=2.000 / 10.000=0,2$ veya $\% 20$

Buna göre varlığın hem maliyet değeri hem de birikmiş amortismanı \%20 artırılacaktır. Fark ise maddi olmayan duran varlıklar yeniden değerleme artışları olarak özkaynaklar içerisinde yer alacaktır.

2.. Haklar I 4.000
2.. Birikmiş Amortismanlar 2.000
5..Maddi Olmayan DV. Yen.Değ. Artışları 2.000

Yukarıdaki örnekte eğer gerçeğe uygun değer 9.000 TL olarak tespit edilmiş olsaydı,

Değer düşüklüğü oranı $=1.000 / 10.000=0,10$ veya $\% 10$ olacaktır.

Bundan dolayı, varlığın maliyet değeri ve birikmiş amortismanı \%10 azaltılacak ve fark için karşılık ayrılacaktır. 
2.. Birikmiş Amortismanlar

6.. Karşılık Giderleri

1.000

2..Maddi Olmayan DV. Değ. Düşüklüğü Karş1lığg 2.000

Burada yapılan kayıtlardan da görüneceği gibi TMS/TFRS uygulamaları sonucu maddi olmayan duran varlı̆̆ın, dolayısıyla hem duran varlık toplamının hem de aktif toplamının değerinde azalış da artış da görünebilir. Ayrıca, değer artışı olması durumunda özkaynaklar toplamı artacaktır. Bu durum ilgili oranları farklı şekillerde değiştirecektir.

\section{TMS 40 Yatırım Amaçlı Gayrimenkuller}

Kira geliri veya sermaye kazancı ya da her ikisini birden elde etmek amacı ile elde tutulan gayrimenkuller yatırım amaçlı gayrimenkuller olarak sınıflandırılmaktadır. Yatırım amaçlı gayrimenkuller işletmenin diğer varlıklarından büyük ölçüde bağımsız nakit akışı yaratmaktadır. Bir duran varlık yatırım amaçlı gayrimenkul olarak sınıflandırıldığında gerçeğe uygun değer ile değerlendirilmekte ve mali tablolarda yer almaktadır. Tam set TMS/TFRS'de gerçeğe uygun değerin belirlenememesi durumunda işletme yatırım amaçlı gayrimenkulünü TMS 16'da belirtilen maliyet yöntemi ile ölçer. KOBİ TFRS'de bir duran varlığın yatırım amaçlı gayrimenkul olarak sınıflandırılabilmesi için gerçeğe uygun değerin tespiti şarttır (RG 17.03.2006, sayı: 26111; Gücenme Gençoğlu vd., 2013)

Örneğin: İşletme kullanmakta olduğu 100.000 TL maliyet değerine ve 40.000 TL birikmiş amortismana sahip bir binasını kiraya vermiştir. Binanın gerçeğe uygun değeri 200.000 TL ise yapılması gereken kayıt aşağıdaki gibi olacaktır.

2.. Yatırım Amaçlı Gayrimenkuller

2.. Birikmiş Amortismanlar

2.. Binalar

6.. Olağan Gelir ve Karlar
200.000

40.000

100.000

140.000

$\mathrm{Bu}$ işlem sonucunda işletmenin duran varlıklarından 60.000 TL defter değerine sahip binalar yok olmuş fakat 200.000 TL değerinde yeni bir varlık gelmiştir. Böylece işletmenin duran varlıklarında ve dolayısıyla toplam aktiflerinde 140.000 TL değerinde artış olmuştur. Bununla birlikte, işletmenin dönem karında da aynı tutarda artış gerçekleşmiştir. Duran varlıkların artması sonucu duran varlık devir hızı azalacaktır. Bununla birlikte, dönem karındaki ve toplam varlıklardaki artış varlıkların karlılığı oranının hem payını hem de paydasını etkileyecek ve varlıkların karlılığı oranı değişecektir. 


\section{Ertelenmiş Vergi Varlığı ve Ertelenmiş Vergi Borcu}

Zamanlama ve değerleme farklılıklarından dolayı uluslararası muhasebe standartları ile Vergi Usul Kanunu (VUK) arasında uyumsuzluklar ortaya çıkmaktadır. Buna göre TMS/TFRS'nin bu dönem gelir veya gider olarak kabul ettiği bir işlem VUK'na göre bu dönem gelir veya gider olarak kabul edilmeyebilir. Bunun tam tersi de mümkündür. Veya değerleme yöntemlerinde de farklılıklar olabilir (RG 28.03.2006, sayı: 26122). Örneğin, Uluslararası Muhasebe Standartlarına göre hesaplanan amortisman gideri fazla veya az olabilir. Uluslararası Muhasebe Standartları tüm duran varlıklar için kıst amortismanı kabul etmiştir. Mevcut uygulamamızda ise sadece taşıtlarda kıst amortisman kullanılmaktadır. Aynı şekilde tam set TMS/TFRS uygulayan işletmelerin yeniden değerleme uygulaması sonucu amortisman tutarı da değişecektir (Gücenme Gençoğlu vd., 2013).

Tüm bunlar neticesinde Uluslararası Muhasebe Standartlarına göre hesaplanan muhasebe karı (dönem karı) ile vergi matrahı arasında farklılıklar oluşacaktır. Bu durum ise geçici farklar olarak ortaya çıkacaktır. Özetle, eğer Uluslararası Muhasebe Standartlarının gider kabul ettiği bir işlem VUK tarafindan bu dönem gider olarak kabul edilmez ise tutar vergi matrahına eklenecek ve işletme daha fazla vergi ödeyecektir. Fazladan ödenen bu vergi tutarı ertelenmiş vergi varlığı olarak duran varlıklarda yer alacaktır. Ĕger ertelenmiş vergi varlığı özkaynaklar içerisinde yer alan bir hesaptan dolayı ortaya çıkmamış ise bunun vergi gelir etkisi de gelir tablosunda dönem net karından önce ve dönem net karını artıracak şekilde yer alacaktır. Uluslararası Muhasebe Standartlarının gelir olarak kabul ettiği fakat VUK tarafından henüz gelir olarak kabul edilmeyen tutarlar ise vergi matrahının hesaplanmasında indirim olarak yer alacak ve böylece işletmenin ödeyeceği vergi tutarı bu dönem için azalacaktır. Fakat gelir gerçekleştiği dönemde bunun vergisi ödeneceği için işletme açısından ertelenmiş vergi borcu doğuracak ve uzun vadeli yabancı kaynaklar içerisinde yer alacaktır. Bunun gider etkisi, gelir etkisine benzer şekilde gelir tablosunda dönem net karından önce muhasebe karından indirim olarak yer alacaktır (RG 28.03.2006, sayı: 26122).

\section{TMS 23 Borçlanma Maliyetleri}

Tam set TMS/TFRS'lerde borçlanma maliyetleri eğer kullanıma veya satışa hazır hale getirilmesi zorunlu olarak uzun süre alan varlıkların yani özellikli varlıkların elde edilmesi, inşası veya üretimi ile doğrudan ilgili ise varlığın maliyetine dahil edilir (RG 09.11.2005, sayı: 25988). Böylece ilgili varlığın değeri ve varlık toplamı bilançoda daha büyük görünecektir. Bu durum varlıklar ile ilgili oranları da değiştirecektir. Diğer yandan dönemin finansman giderleri azalırken dönem karı artacaktır. Buna rağmen, KOBİ TFRS' de borçlanma maliyetlerinin tamamı gider olarak kaydedilmektedir (RG 01.11.2010, sayı: 27746).

\section{Dağıtılmayan Sabit Genel Üretim Giderleri}

Üretilen mamullerin maliyeti direkt işçilik, direkt ilk madde ve malzeme ve genel üretim giderleri toplamından oluşmaktadır. Uluslararası Muhasebe Standartları açısından 
farklılık ise genel üretim giderlerinin sabit kısmının ürünlere dağıtımında ortaya çıkmaktadır. Buna göre işletme sabit genel üretim giderlerini normal kapasiteye göre dağıtmalıdır. Diğer bir değişle TMS/TFRS'ye göre işletme normal kapasitenin altında üretim yaparsa üretilen ürünlere sabit genel üretim giderleri normal kapasiteye göre dağıtılacak ve birim maliyetlerin artması engellenecektir (RG 15.01.2005, say1: 25701). Bu şekilde bilançoda stokların değeri daha düşük görünecektir.

Dağıtılmayan sabit genel üretim giderleri ise gelir tablosunda satılan malların maliyeti ile brüt kar arasında dağıtılmayan sabit genel üretim giderleri hesabı olarak yer alacak, yani satılan malin maliyetine dahil edilecektir (Gücenme Gençoğlu vd., 2013: 286). Bu durum brüt karın o dönem için düşmesine ve brüt kar marjının azalmasına neden olacaktır. Üretilen mamullerin satılması durumunda ise satılan malların maliyeti daha düşük olacak ve böylece brüt kar artacaktır. Diğer bir değişle brüt kar marjı yükselecektir. Özetle, eğer üretilen mamul aynı dönem satılırsa brüt kar marjında bir değişiklik olmayacaktır. Eğer normal kapasite veya üzerinde üretim yapılırsa tüm maliyetler üretilen ürünlere yansıtılacağı için herhangi bir farklılık yaratmayacaktır.

Örneğin: Üretilen mamule ilişkin direkt ilk madde ve malzeme $15.000 \mathrm{TL}$, direkt işçilik 9.000 TL, değişken genel üretim gideri 3.000 TL ve sabit genel üretim gideri 4.000 TL'dir. Normal kapasite 20.000 birim ve üretim miktarı 16.000 birim ise yapılması gereken işlem aşağıdaki gibi olur.

Yukarıdaki verilere göre işletme $16.000 / 20.000=0,80$ veya $\% 80$ kapasite ile çalışmaktadır. Buna göre sabit genel üretim giderlerinin de $\% 80$ 'i yani 4.000 x $0,80=3.200$ TL'lik kısmı üretilen mamule yüklenir. Üretime yüklenemeyen 800 TL (4.000-3.200=800 TL) ise dağıtılmayan sabit genel üretim maliyeti olarak gelir tablosunda satılan malların maliyeti ile brüt kar arasında yer alan hesaba kayıt edilir.

1.. Yar1 Mamul-Üretim Hs.

6.. Dağıtılmayan Sabit Genel Üretim Maliyeti

7..D.İ.M.M. Giderleri Yansitma Hs.

7..Dir. İşçilik Gid. Yansıtma Hs.

7..GÜG Yansitma Hs.
30.200

800

15.000

9.000

7.000

$\mathrm{Bu}$ işlem sonucunda işletmenin stok tutarı, dolayısıyla dönen varlık ve aktif toplamı daha düşük görünecektir. Üretilen mamulün satılmaması durumunda ise dağıtılmayan kısım gider yazıldığı için işletmenin brüt kar ve dönem karı daha düşük olacaktır. Tüm bu işlemler ilgili finansal oranları da farklı şekilde etkileyecektir.

\section{Diğer}

TMS/TFRS'ye göre faiz gelir ve giderleri gelir tablosunda ayrı bir grup olarak yer almakta ve böylece mali tablo analizinde sıklıkla kullanılmakta olan FVÖK değerinin belirgin 
olması sağlanmaktadır. Diğer bir değişiklikte gelir tablosunda olağandışı gelir ve karlar ile olağandışı gider ve zararların yerine olağan gelir ve karlar ve aynı zamanda olağan gider ve zararlar hesabının yer almasıdır. Diğer bir değişle artık hiçbir işlem olağandışı olarak kayıt edilmemektedir (Gücenme Gençoğlu vd., 2013).

\section{SONUÇ VE DEĞERLENDİRME}

Uluslararası Muhasebe ve Raporlama Standartlarının benimsenmesinin mali tablolar ve buna bağlı olarak mali tablolar analizi üzerindeki etkileri tartışmalı konulardan biri haline gelmiştir. Bu bağlamda, literatürde değişik ülkelere özgü birçok çalışma bulunmaktadır. Fakat çalışmalarda birbirinden farklı bulgular elde edilmiştir. Bunun nedeni ülkelerin muhasebe sistemlerindeki veya işletmelerin faaliyetlerindeki farklılıklar olabilir.

Bu çalışma ile TMS/TFRS uygulamalarının mali tablolar ve oran analizi üzerindeki muhtemel etkileri tartışılmaktadır. Bu amaçla bazı TMS/TFRS uygulamalarının mali tablolarda ve finansal oranlarda ne tür değişime neden olabileceği örnekler yardımıyla açıklanmıştır. Daha önce yapılmış bazı çalışmalarda TMS/TFRS'ye göre mali tablolarını hazırlayan işletmeler üzerinde araştırma yapılmıştır. Fakat Türkiye'de muhasebe kayıtları Uluslararası Muhasebe Standartlarına göre tutulmamakta, sadece borsaya kota olmuş işletmeler yıl sonlarında mali tablolarını bu standartlara uygun hale getirmektedirler.

TMS/TFRS uygulamaları sonucu yapılması gereken kayıt örnekleri incelendiğinde farklı standartların finansal oranlar üzerinde farklı etkilerinin olduğu görülmektedir. Bir standardın uygulanması bir oranda artışa neden olurken diğer bir standardın uygulanması aynı oran üzerinde azalışa neden olabilir. Aynı şekilde, işletme faaliyetlerinin özelliğine bağlı olarak bir standart bir oranın artmasına da azalmasına da neden olabilir.

Tüm bu nedenlerden dolayı TMS/TFRS uygulamalarının oranlar üzerindeki etkisini azalış veya artış olarak yorumlamak doğru olmayacaktır. Bunun yerine değişime neden olan işlemlerin veya hesapların anlaşılması daha doğru olacaktır. Oran analizinde çoğu oran için kesin rakamlar mevcut değildir. Bundan dolayı elde edilen oranlar işletmenin geçmiş yıl oranları ve sektör ortalaması ile karşılaştırılmalıdır. Değişik muhasebe sistemlerinin uygulandığı ülkelerde de mali tablolar analizi bu esasa göre gerçekleştirilmektedir. Sonuç olarak, oran analizinde karşılaştırma aynı muhasebe sistemine göre hazırlanmış finansal tablolar arasında mümkündür. $\mathrm{Bu}$ nedenle TMS/TFRS uygulamaları sonucu mali tablolarda ortaya çıkacak yeni hesap ve hesap gruplarının anlaşılması ve mevcut yılın TMS/TFRS'ye göre hazırlanmış geçmiş yıllara ait mali tablolar ve sektördeki işletmeler ile karşılaştırılması uygun olacaktır. 


\section{KAYNAKLAR}

Ataman, Başak- Özden, Evrim Altuk (2009),’Tek Düzen Hesap Planına Göre Hazırlanan Finansal Tabloların UFRS'ye Uyarlanması ve Rasyo Yöntemi ile Analizi”, Muhasebe ve Finansman Dergisi, Say1 44, ss.59-73.

Balc1, Baki Rıza (2012), “TFRS'lerin Oran Analizine Etkileri”, Journal of Yasar University, Cilt 28, Sayı 7, ss.4687 - 4707.

Blanchette, Michel- Racicot, François-Éric - Girard, Jean-Yves (2011), “TheEffects of IFRS on Financial Ratios: EarlyEvidence in Canada", Certified General Accountants Association of Canada, ISBN 978-1-55219-641-0. http://www.cga-canada.org/enca/ResearchReports/ca_rep_2011-03_IFRS_early_adopters.pdf (26-04-2014)

Blanchette, Michel- Racicot, François-Éric- Sedzro, Komlan (2013), "IFRS Adoption in Canada: An Empirical Analysis of the Impact on Financial Statements", Certified General Accountants Association of Canada, ISBN 978-1-55219-671-7. http://www.cga-canada.org/en-ca/ResearchReports/ca_rep_2013-10-03_IRFS.pdf (2604-2014)

Dimitrios, Balios- Nikolaos, Eriotis- Konstantinos- Paraskevopoulos- Dimitrios, Vasiliou (2013), "Theimpact of IFRS on ratios of listedandnewlistedcompanies of Athens Exchange”, International Journal of Business andSocialResearch (IJBSR), Volume 3, No.5, pp. 139-157.

Elitaş, Cemal (2010), “Türkiye Muhasebe Standartları / Türkiye Finansal raporlama Standartlarının Benimsenmesinin Bazı Temel Finansal Oranlar Üzerindeki Etkisi Üzerine Uygulamalı Bir Değerlendirme”, Muhasebe ve Denetime Bakış, Sayı 30, ss.57-68.

Gücenme Gençoğlu, Ümit- Özerhan, Yıldız- Karabınar, Selahattin (2013), “Türkiye Finansal Raporlama Standartları", Sakarya Üniversitesi Sürekli Eğitim Uygulama ve Araştırma Merkezi, Sakarya.

Pazarskis, Michail- Alexandrakis, Alexandros- Notopoulos, Panagiotis- Kydros, Dimitrios (2011), "IFRSAdoptionEffects in Greece: Evidencefromthe IT Sector", Management of International Business and Economics Systems 2011 Conference (MIBES),pp. 6071.

Resmi Gazete (RG) 15.01.2005 tarih ve 25701 sayılı "Stoklara İlişkin Türkiye Muhasebe Standardı (TMS 2) Hakkında Tebliğ"

Resmi Gazete (RG) 09.11.2005 tarih ve 25988 sayılı "Borçlanma Maliyetlerine İlişkin Türkiye Muhasebe Standardı (TMS 23) Hakkında Tebliğ"

Resmi Gazete (RG) 09.12.2005 tarih ve 26018 sayılı "Hasılata İlişkin Türkiye Muhasebe Standardı (TMS 18) Hakkında Tebliğ" 
Resmi Gazete (RG) 31.12.2005 tarih ve 26040 sayılı "Maddi Duran Varlıklara İlişkin Türkiye Muhasebe Standardı (TMS 16) Hakkında Tebliğ"

Resmi Gazete (RG) 16.03.2006 tarih ve 26110 sayılı "Satış Amaçlı Elde Tutulan Duran Varlıklar Ve Durdurulan Faaliyetlere İlişkin Türkiye Finansal Raporlama Standardı (TFRS 5) Hakkında Tebliğ"

Resmi Gazete (RG) 17.03.2006 tarih ve 26111 sayılı "Maddi Olmayan Duran Varlıklara İlişkin Türkiye Muhasebe Standardı (TMS 38) Hakkında Tebliğg”

Resmi Gazete (RG) 17.03.2006 tarih ve 26111 sayılı "Yatırım Amaçlı Gayrimenkullere

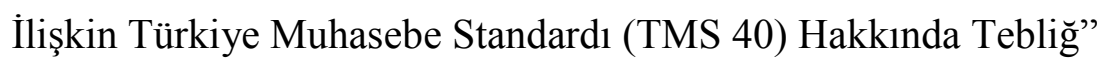

Resmi Gazete (RG) 28.03.2006 tarih ve 26122 sayılı "Gelir Vergilerine İlişkin Türkiye Muhasebe Standardı (TMS 12) Hakkında Tebliğ"

Resmi Gazete (RG) 01.11.2010 tarih ve 27746 sayılı “KOBİ'ler İçin Türkiye Finansal Raporlama Standardı Hakkında Tebli ̆̆"

Stent, Warwick, Bradbury, Michael ve Hooks, Jill (2010), "IFRS in New Zealand: Effects on Financial Statements and Ratios", Pacific Accounting Review, Vol. 22 No. 2, pp. 92 107.

Terzi, Serkan- Oktem, Recep- Sen, Ilker Kiymetli (2013), "Impact of Adopting International Financial Reporting Standards: Empirical Evidence fromTurkey”, International Business Research; Vol. 6, No. 4, pp. 55-66. 
